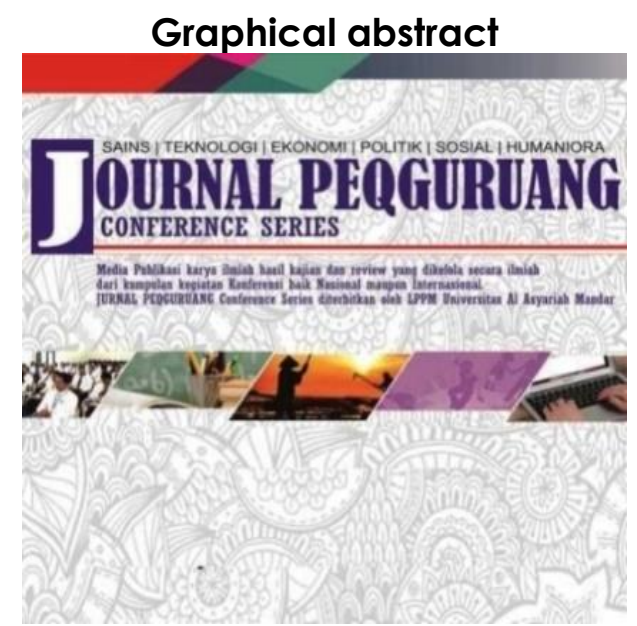

\section{PENGARUH MEDIA SOSIAL FACEBOOK TERHADAP PERILAKU PELAJAR DI DESA PASIANG KECAMATAN MATAKALI KABUPATEN POLEWALI MANDAR}

\author{
${ }^{1 *}$ Mawaddah Warahma, ${ }^{2}$ Syamsu Alam, ${ }^{3}$ Ade Rahayu \\ *Program Studi Pendidikan Pancasila dan \\ Kewarganegaraan, Fakultas, Keguruan dan Ilmu \\ Pendidikan, Universitas Al Asyariah Mandar \\ 1mawaddahwarahma02121998@gmail.com, \\ 2syamsualam39@yahoo.com, \\ 3aderahayu@mail.unasman.ac.id
}

\begin{abstract}
This research is motivated by the development of Facebook which is increasingly familiar and much loved by internet users, especially teenagers who have indicated a strong role in facilitating users to do social interaction through communication. The purpose of this study was to determine the effect of Facebook social media on student behavior in Pasiang Village, Matakali Subdistrict. This type of research is a quantitative descriptive study that aims to find out how the influence of Facebook social media on Student behavior in Pasiang village. The population in this study was 247 students from junior to senior high school with a sample of 49 students. Using purposive sampling technique. The data collection techniques were carried out through questionnaire, interview and observation techniques. Based on the results of descriptive analysis techniques and infrential analysis on Facebook social media on student behavior shows that there is no significant difference between the influence of Facebook social media on behavior this is evidenced by the relationship between Facebook social media on student behavior $0.130 \%$ and the level of contribution between Facebook social media on student behavior by $1.69 \%$. This can be proved by the calculated $t$ value $(1,112)<t$ table $(1,677)$, so it can be said that social media facebook has no effect on student behavior.
\end{abstract}

Keywords: Facebook, Behavior, Students.

\begin{abstract}
Abstrak
Penelitian ini dilatar belakangi dengan perkembangan facebook yang semakin familiar dan banyak disenangi oleh pengguna internet khususnya remaja yang berindikasi memiliki peran yang kuat dalam memfasilitasi penggunanya untuk melakukan interaksi sosial melalui komunikasi. Tujuan penelitian ini untuk mengetahui pengaruh sosial media facebook terhadap perilaku pelajar di Desa Pasiang Kecamatan Matakali.Jenis penelitian ini adalah penelitian deskriptif kuantitatif yang bertujuan untuk mengetahui Bagaimana Pengaruh sosial media facebook terhadap perilaku Pelajar di desa pasiang. Populasi dalam penelitian ini adalah 247 pelajar dari tingkat SMP sampai SMA dengan sampel 49 jumlah pelajar. Menggunakan teknik purposive sampling. Adapun teknik pengumpulan data dilakukan melalui teknik angket, Wawancara dan Observasi. Berdasarkan hasil Teknik analisis deskriptif dan analisis infrensial pada sosial media facebook terhadap perilaku pelajar menunjukkan bahwa tidak adanya perbedaan yang signifikan antara pengaruh sosial media facebook terhadap perilaku hal ini dibuktikan dengan hubungan antara media sosial facebook terhadap perilaku pelajar $0.130 \%$ dan tingkat kontribusi antara media sosial facebook terhadap perilaku pelajar sebesar $1,69 \%$. Hal tersebut dapat dibuktikan dengan nilai $\mathrm{t}$ hitung $(1,112)<\mathrm{t}$ tabel $(1,677)$, maka dapat di dikatakan bahwa sosial media facebook tidak berpengaruh terhadap perilaku pelajar.
\end{abstract}

Kata Kunci: Facebook, Perilaku, Pelajar.

Article history

DOI: http://dx.doi.org/10.35329/ip.v2i2.1649

Received : 15 September 2020 | Received in revised form : 24 September 2020 | Accepted : 13 Oktober 2020 


\section{PENDAHULUAN}

Teknologi merupakan suatu alat yang digunakan sebagai media untuk menunjang kehidupan sehari-hari. Dimana arus globalisasi yang menuntut perkembangan zaman pada saat ini, memang dianjurkan untuk setiap manusia untuk mengunakan teknologi tersebut. Dalam memenuhi kehidupannya manusia saat ini tidak jauh dari teknologi, karena tenanga manusia pada saat ini terbatas untuk dapat menjangau sesuatu kebutuhan yang diinginkan (Ega: 2014)

Salah Satu media teknologi pada saat ini adalah komputer dimana tujuan salah satunya adalah untuk mengakses jaringan internet yang digunakan oleh manusia untuk mengakses internet, yang dimana dalam internet tersebut terdapat media social yang digunakan manusia untuk saling berhubungan satu sama lain ataupun untuk keperluan lainnya yang bermanfaat bagi kehidupannya. Tersedianya dan terpopulernya medsos saat ini salah satunya yang paling populer adalah Facebook (Hanafi: 2016)

Facebook adalah sebuah layanan jejaring sosial yang diluncurkan pada bulan Februari 2004, didirikan oleh Mark Zuckerberg bersama teman sekamarnya dan sesama mahasiswa Universitas Harvard, Eduardo Saverin, Andrew Mc Collum, Dustin Moskovitz dan Chris Hughes (Syaeba, M: 2019).

Facebook merupakan medsos yang paling popular pada tahun 2000an, dan salah satu fungsinya adalah sebagai media komunikasi jarak jauh dengan menggunakan media. Media ini sangat diminati dari segala kalangan baik itu anak-anak sampai orang tua. Selain mudah dingunakan juga sangat membuat nyaman penggunanya karena di lengkapi berbagai fitur, yang membantu penggunanya dalam berkomunikasi jarak jauh dengan mudah (Nasrullah: 2015)

Namun seiring perkembangnya media sosial facebook Yang semakin pesat ternyata ada dampakdampak yang didapat oleh penggunanya khususnya pelajar. Hal ini dapat dikarenakan ketidakmatangan seorang remaja dalam mengenali identitas diri maupun lingkungannya. Mengingat usia remaja merupakan masa pencarian dan pengukuhan jati diri sebelum menginjak usia dewasa. Remaja bahasa aslinya adalah adolescence, berasal dari bahasa latin yang artinya "tumbuh untuk mencapai keuntungan". Perkembangan lebih lanjut istilah adolescence sesungguhn ya memiliki arti yang luas, yakni mencakup kematangan mental, emosional, sosial, dan fisik. Secara psikologis, remaja adalah suatu usia yang menempatkan individu menjadi terintegrasi ke dalam masyarakat dewasa, anak tidak merasa bahwa dirinya berada di bawah tingkat orang yang lebih tua melainkan merasa sama, atau paling tidak sejajar (Prisgunanto: 2015)

Remaja yang masih berjiwa labil dan emosional sering salah menafsirkan apa yang mereka dapatkan baik dari media massa maupun dari situs pertemanan.
Keadaan yang seperti demikian menjadikan remaja sering terpancing rasa keingintahuannya untuk mencoba apa yang ditawarkan kepada mereka melalui media- media tersebut yang kemudian memunculkan perubahan perilaku baik itu yang positif maupun negatif pada diri remaja (Yusuf: 2017)

\section{METODE PENELITIAN}

\section{Jenis Penelitian}

Jenis penelitian tersebut kualitatif deskriptif. Kualitatif Dan dideskripsikan secara deduksi yang berangkat dari teori-teori umum, lalu dengan observasi untuk menguji validitas keberlakuan teori tersebut ditariklah kesimpulan. Kemudian dijabarkan secara deskriptif, karena hasilnya akan diarahkan untuk menggambarkan atau mendeskripsikan data yang diperoleh dan untuk menjawab rumusan masalah dari penelitian tersebut.

\section{Desain Penelitian}

Penelitian ini dibahas lebih dari satu variabel, yaitu variabel bebas yaitu media sosial facebook $(\mathrm{X})$ dan variabel terikat yaitu perilaku pelajar (Y).

\section{Tempat dan Waktu Penelitian}

Penelitian tersebut dilakukan di Desa Pasiang Kecamatan Matakali Kabupaten Polewali Mandar. Dan penelitian dilakukan selama 6 bulan dari Desember 2019 sampai Juli 2020.

\section{Populasi dan sampel}

1. Populasi penelitian

Populasi adalah keseluruhan jumlah yang terdiri atas objek atau subjek yang mempunyai karakteristik dan kualitas tertentu, terlihat pada tabel 3.1 populasi pelajar di Desa Pasiang.

\begin{tabular}{|c|c|c|c|}
\hline NO & DUSUN & $\begin{array}{c}\text { JUMLAH } \\
\text { PELAJAR(SMP\&SM } \\
\text { A) }\end{array}$ & $\underset{\text { K }}{\text { JUMLAHK }}$ \\
\hline & TABONE & 89 & 434 \\
\hline & $\begin{array}{l}\text { BUTTU } \\
\text { LAMBA }\end{array}$ & 55 & 318 \\
\hline & $\begin{array}{l}\text { TOJANGA } \\
\mathrm{N}\end{array}$ & 57 & 286 \\
\hline & SEPPONG & 46 & 135 \\
\hline & JUMLAH & 247 & 1172 \\
\hline
\end{tabular}

Sumber: Bagian pemerintahan Desa Pasiang 2019

\section{Sampel Penelitian}

Jumlah sampel yang di terapkan oleh peneliti sebanyak 49 orang dari 100 pekajar yang ada di desa pasiang.

\section{Variabel penelitian}

Sugiyono (2017: 39) "variabel penelitian adalah suatu atribut seseorang atau objek yang mempunyai 
variasi tertentu yang telah ditetapkan antara satu orang dengan yang lain atau suatu objek dengan objek yang lain. Dalam penelitian ini terdiri dari dua variabel yaitu: variabel bebas (sosial media facebook) dan variabel terikat (perilaku pelajar) (Sondoklangi: 2016).

\section{Defenisi Operasional Variabel}

1. Media Sosial facebook

Saluran atau saran pergaulan sosial online di dunia maya (internet). Sosial media juga adalah media yang memungkinkan pengguna merepresantasikan dirinya maupun berinteraksi, bekerja sama, berbagi berkomunikasi dengan pengguna lain.

2. Perilaku

Serangkaian tindakan yang dibuat oleh individu, sistem, atau entitas buatan dalam hubungannya dengan dirinya sendiri atau lingkungan, yang mencakup sistem atau organisme lain disekitarnya serta lingkungan fisik.

\section{Teknik Pengumpulan Data}

1. Angket merupakan teknik pengumpulan data yang dilakukan dengan cara memberi seperangkat pertanyaan atau pernyataan tertulis kepada responden untuk di jawab.

2. Wawancara merupakan teknik pengumpulan data yang dilakukan dengan cara memberi seperangkat pertanyaan kepada narasumber secara tatap muka dengan sumber data atau narasumber.

3. metode observasi yaitu penelitian ini mengamati secara langsung dengan mengamati keadaan di lokasi penelitian.

4. Metode dokumentasi yaitu metode pengumpulan data yang diperoleh dari lapangan dan keterangannya secara tertulis, tergambar, terekam atau tercetak.

\section{Instrumen Penelitian}

Instrumen penelitian merupakan alat yang dipergunakan oleh peneliti dalam mengumpulka data sehingga pekerjaannya dapat lebih mudah diolah.

\section{Teknik Analisis Data}

Teknik analisis data dalam penelitian kuantitatif menggunakan statistik. Terdapat dua macam statistik yang digunakan yaitu statistik deskriptif dan statistik inferensial.

$1 \quad$ Analisis statistik deskriptif

Analisis deskriptif adalah analisis yang dilakukan untuk menilai karakteristik dari sebuah data.

$$
P=F / n \times 100 \%
$$

$$
\begin{aligned}
& \text { Ket: } \\
& \mathrm{P} \quad=\text { Presentase } \\
& \mathrm{F} \quad=\text { Frekuensi jawaban responden } \\
& \mathrm{n} \quad \text { Jumlah Responden }
\end{aligned}
$$

\section{Analisis Statistik Infrensial}

Digunakan untuk menguji hipotesis penelitian. Untuk mengetahui tingkat korelasi/hubungan antara variable $\mathrm{x}$ dengan variable $\mathrm{y}$. Analisis infrensial digunakan untuk menguji hipotesis penelitian.

$$
r_{X Y}=\frac{N \Sigma X Y-(\Sigma X)(\Sigma Y)}{\sqrt{\left.\left\{N . \Sigma X^{2}-(\Sigma X)^{2}\right\} N \Sigma \Sigma Y^{2}(\Sigma Y)^{2}\right\}}}
$$

Ket:

r_xy $=$ Koefisien korelasi antara variabel $\mathrm{x}$ dan $\mathrm{y}$.

$\mathrm{Xy}=$ jumlah hasil perkalian antara variabel $\mathrm{x}$

dengan variabel y

$x=$ jumlah nilai setiap item

$\mathrm{y}=$ jumlah nilai konstan

$\mathrm{n}=$ jumlah subjek penelitian

Untuk mengetahui apakah terdapat hubungan yang signifikan antara pengaruh media sosial facebook terhadap perilaku pelajar maka dilakukan pengujian signifikasi dengan uji -t dengan rumus sebagai berikut:

$$
t=\frac{r \sqrt{N-2}}{\sqrt{1-r^{2}}}
$$

Adapun kaidah pengujian dinyatakan sebagai berikut:

1. Jika t hitung $\geq \mathrm{t}$ tabel, maka terdapat hubungan signifikan

2. Jika $\mathrm{t}$ hitung $\leq \mathrm{t}$ tabel, maka tidak terdapat hubungan signifikan

Sedangkan untuk menyatakan besar kecilnya kontribusi variabel $\mathrm{x}$ terhadap variabel y dapat ditentukan dengan persamaan koefisien determinasi sebagai berikut

$$
\mathrm{Kd}=\mathrm{R}^{2} \mathrm{x} 100 \%
$$

Ket:

$\mathrm{Kd}=$ Koefisien determinasi

$\mathrm{R}^{2}=$ Besarnya koefisien korelasi ganda

\section{HASIL DAN PEMBAHASAN}

\section{Hasil Analisis Statistik deskriptif}

Berdasarkan hasil angket penelitian yang telah diperoleh dari seluruh pelajar di Desa Pasiang yang terdiri dari 49 responden. Hasil penelitian dari analisis deskriptif yang berkaitan dengan skor media sosial facebook pada seluruh pelajar di kelompokkan dalam tabel presentase sebagai berikut:

\section{Media sosial facebook}

Tabel 4.4

Frekuensi mengaupdate statu disosial media facebook

\begin{tabular}{clcc}
\hline NO & Jawaban & Frekuensi & $\begin{array}{l}\text { Presenta } \\
\text { se }\end{array}$ \\
\hline 1. & Sangat setuju & 15 & $33 \%$ \\
\hline 2. & Setuju & 13 & $28 \%$ \\
\hline 3. & Tidak setuju & 8 & $17 \%$ \\
\hline 4. & Sangattidak setuju & 13 & $28 \%$ \\
\hline & Jumlah & 49 & $100 \%$ \\
\hline
\end{tabular}

Sumber: Hasil olah data Agket Penelitian, 2020 
Berdasarkan data pada table 4.4 maka dapat disimpulkan bahwa. Frekuensi mengupdate status responden adalah sebanyak 15 responden atau 33\% yang berada pada jawaban "Sangat setuju" , sebanyak 13 responden atau sebesar $28 \%$ yang berada pada jawaban "setuju", sebanyak 8 responden atau sebesar 17\% yang berada pada jawaban "tidak setuju" dan sebanyak 13 responden atau sebesar 28\% yang menjawab "sangat tidak setuju".

Table 4.5

menyukai/mengomentari syatus akun yang lain

\begin{tabular}{llcc}
\hline No. & Jawaban & Frekuensi & Presentase \\
\hline 1. & Sangat setuju & 12 & $26 \%$ \\
\hline 2. & Setuju & 17 & $37 \%$ \\
\hline 3. & Tidak setuju & 9 & $20 \%$ \\
\hline 4. & Sangat tidak setuju & 11 & $24 \%$ \\
\hline & Jumlah & 49 & $100 \%$ \\
\hline
\end{tabular}

Sumber: Hasil olah data Agket Penelitian, 2020.

Berdasarkan data pada table 4.5 maka dapat disimpulkan bahwa. Frekuensi menyukai/mengomentari status akun lain adalah sebanyak 12 responden atau $26 \%$ yang berada pada jawaban "Sangat setuju", sebanyak 17 responden atau sebesar 37\% yang berada pada jawaban "setuju", sebanyak 9 responden atau sebesar 20\% yang berada pada jawaban "tidak setuju" dan sebanyak 11 responden atau sebesar 24\% yang menjawab "sangat tidak setuju".

Tabel 4.6

mengirimkan pesan

\begin{tabular}{|c|c|c|c|}
\hline $\begin{array}{l}\mathrm{N} \\
\mathrm{o} .\end{array}$ & Jawaban & Frekuensi & Presentase \\
\hline 1. & Sangat setuju & 15 & $33 \%$ \\
\hline 2. & Setuju & 25 & $55 \%$ \\
\hline 3. & Tidak setuju & 6 & $13 \%$ \\
\hline \multirow[t]{2}{*}{4.} & Sangat tidak setuju & - & - \\
\hline & Jumlah & 49 & $100 \%$ \\
\hline
\end{tabular}

Sumber: Hasil olah data Agket Penelitian, 2020

Berdasarkan data pada table 4.6 maka dapat disimpulkan bahwa. sebanyak 15 responden atau 33\% yang berada pada jawaban "Sangat setuju" sebanyak 25 responden atau sebesar $55 \%$ yang berada pada jawaban "setuju", sebanyak 6 responden atau sebesar 13\% yang berada pada jawaban "tidak setuju" terhadap frekuensi mengirimkan pesan

\section{Perilaku pelajar}

Tabel 4.20

rasa peduli dengan sesama

\begin{tabular}{clcc}
\hline No. & \multicolumn{1}{c}{ Jawaban } & Frekuensi & Presentase \\
\hline 1. & Sangat setuju & 5 & $11 \%$ \\
\hline 2. & Setuju & 8 & $17 \%$ \\
\hline 3. & Tidak setuju & 27 & $60 \%$ \\
\hline 4. & Sangat tidak setuju & 6 & 13 \\
\hline & Jumlah & 49 & $100 \%$ \\
\hline
\end{tabular}

Sumber: Hasil olah data Agket Penelitian, 2020.

Berdasarkan data pada table 4.20 maka dapat disimpulkan bahwa. sebanyak 5 responden atau $11 \%$ yang berada pada jawaban "Sangat setuju" sebanyak 8 responden atau sebesar $17 \%$ yang berada pada jawaban "setuju", sebanyak 27 responden atau sebesar 60\% yang berada pada jawaban "tidak setuju" dan sebanyak 6 responden atau 13\% yang menjawab "sangat tidak setuju".

Tabel 4.22

Pemberian data/informasi yang tidak benar

\begin{tabular}{clcc} 
No. & Jawaban & Frekuensi & Presentase \\
\hline 1. & Sangat setuju & 1 & $2 \%$ \\
\hline 2. & Setuju & 2 & $4 \%$ \\
\hline 3. & Tidak setuju & 21 & $44 \%$ \\
\hline 4. & $\begin{array}{l}\text { Sangat tidak } \\
\text { setuju }\end{array}$ & 25 & $55 \%$ \\
\hline & Jumlah & 49 & $100 \%$ \\
\hline
\end{tabular}

Sumber: Hasil olah data Agket Penelitian, 2020.

Berdasarkan data pada table 4.22 maka dapat disimpulkan bahwa. sebanyak 1 responden atau $2 \%$ yang berada pada jawaban "Sangat setuju", sebanyak 2 responden atau sebesar $4 \%$ yang berada pada jawaban "setuju", sebanyak 2 1responden atau sebesar $44 \%$ yang berada pada jawaban "tidak setuju" dan sebanyak 25 responden atau 55\% yang menjawab "sangat tidak setuju".

Tabel 4. 28

kurangnya interaksi sosial secara langsung

\begin{tabular}{cccc} 
N & Jawaban & Frekuensi & Presentase \\
o. & & & \\
\hline 1. & Sangat setuju & 20 & $20 \%$
\end{tabular}




\begin{tabular}{|c|c|c|c|}
\hline 2. & Setuju & 22 & $48 \%$ \\
\hline 3. & Tidak setuju & 3 & $6 \%$ \\
\hline \multirow[t]{2}{*}{4.} & Sangat tidak setuju & 2 & $4 \%$ \\
\hline & Jumlah & 49 & $100 \%$ \\
\hline
\end{tabular}

Sumber: Hasil olah data Agket Penelitian, 2020.

Berdasarkan data pada table 4.28 maka dapat disimpulkan bahwa. sebanyak 20 responden atau $20 \%$ yang berada pada jawaban "Sangat setuju", sebanyak 22 responden atau sebesar $48 \%$ yang berada pada jawaban "setuju", sebanyak 3 responden atau sebesar 6\% yang berada pada jawaban "tidak setuju", dan sebanyak 2 responden atau 4\% yang menjawab "sangat tidak setuju”.

\section{UJI HIPOTESIS}

\section{a. Perhitungan koefisien korelasi dan koefisien} determinasi (KD)

Perhitungan koefisien korelasi digunakan untuk mengetahui hubungan antara variable (X) terhadap variable (Y). hal ini, perhitungan koefisien korelasi digunakan untuk mengetahui tingkat pengaruh sosial media facebook terhadap perilaku pelajar di desa pasiang. Untuk mancari korelasi antara variable (X) terhadap variable (Y) digunakan persamaan korelasi Person Product-Moment sebagai berikut:

$$
r_{x y}=\frac{n \cdot \Sigma X Y-\left(\sum X\right)(\Sigma Y)}{\sqrt{\left.\left\{n \cdot \Sigma X^{2}-(\Sigma X)^{2}\right\} n \cdot \Sigma Y^{2}(\Sigma Y)^{2}\right\}}}
$$

Dik :

$\mathrm{N}=49$

$\mathrm{X}=2.588$

$\mathrm{Y}=2.453$

$\mathrm{XY}=129.713$

$\mathrm{Y}^{2}=125.669$

$\mathrm{X}^{2}=137.174$

$r x y=\frac{49 \cdot(129,713)-(2588)(2453)}{\sqrt{\left\{49 \cdot(137,174)-(2588\}^{2} \cdot\left\{49 \cdot(125,669)(2453)^{2}\right.\right.}}$

$r x y=\frac{(6,355,937)-(6,348,364)}{\sqrt{-(6,721,526)}\}\{6,157,781)-(6,017,209)\}}$

$r x y=\frac{7,573}{\sqrt{\{23,782}\}\{140,572\}}$

$r x y=\frac{7,573}{\sqrt{3,343,083,304}}$

$r x y=\frac{7,573}{57,819}$

$r \times y=0,130$

Dari hasil perhitungan koefisien korealsi diatas, dapat diketahui bahwa sosial media facebook sangat rendah pengaruhnya terhadap perilaku pelajar. merujuk pada buku (sugiyono: 2016), interpretasi koefisien korelasi di bagi kedalam beberapa kriteria sebagai berikut:

\begin{tabular}{cc}
\hline Interval koefisien & Tingkat hubungan \\
\hline $0,00-0,199$ & Sangat Rendah \\
\hline $0,20-0,399$ & Rendah \\
\hline $0,40-0,599$ & Sedang \\
\hline $0,60-0,799$ & Kuat \\
\hline $0,80-1.00$ & Sangat Kuat
\end{tabular}

Sumber: buku metode penelitian uantitatif,kualitatif, dan R\&D; Sugiyono

Dari kriteria diatas didapati bahwa hubungan sosial media facebook sangat rendah terhadap perilaku pelajar dikarenakan dari perhitungan koefisien korelasi didapati hasilnya adalah 0,130 dari interval koefisien yang 0.00-0,199 maka tinkat hubungannya Sangatlah rendah.

Untuk mengetahui besarnya kontribusi variable Y maka dapat dihitung dengan menggunakan persamaan koefisien determinasi sebagai berikut:

$$
\begin{aligned}
& \mathrm{KP}=r^{2} \times 100 \% \\
& \mathrm{Kp}=(0,130)^{2} \times 100 \% \\
& \mathrm{Kp}=0,0169 \times 100 \% \\
& \mathrm{Kp}=1.69 \%
\end{aligned}
$$

Koefisien determinasi yang diperoleh sebesar $1.69 \%$. Hal ini terlihat kontribusi variable $\mathrm{X}$ (media sosial facebook) sangat rendah pengaruhnya terhadap perilaku pelajar yang ada di desa pasiang. Atau dengan kata lain bahwa pengaruh sosial media facebook terhadap perilaku pelajar sebesar $1,69 \%$ dan sisahnya sebesar: $100 \%-1,69 \%=98,31 \%$.

Untuk mengetahui signifikan koefisien korelasi person product moment sebesar 0,130 diatas, digunakan uji $\mathrm{t}$ karena termasuk sampel besar $(\mathrm{n}>30$ dengan rumus:

$$
\begin{aligned}
& t=\frac{r \sqrt{N-2}}{\sqrt{1-r^{2}}} \\
& t=\frac{0,130 \sqrt{49-2}}{\sqrt{1-1.69}} \\
& t=\frac{0,130 \sqrt{47}}{\sqrt{0,69}} \\
& t=\frac{(0,130)(6.85)}{0,8} \\
& t=\frac{0,8905}{0.8} \\
& \mathrm{t}=1,112
\end{aligned}
$$

Berdasarkan perhitungan di atas dengan ketentuan: $d b=\mathrm{n}-1=49-1=48$ dan $\mathrm{a}=0,05$ maka di dapatkan angka $=1,677$. karena t hitung $(1,112)<\mathrm{t}$ tabel $(1,677)$, dengan demikian dapat dikatakan bahwa tidak terdapat hubungan yang signifikan antara pengaruh sosial media facebook terhadap perilaku pelajar. Maka dapat di simpulkan bahwa sosial media facebook tidak berpengaruh terhadap perilaku pelajar.

\section{SIMPULAN}

Berdasarkan keseluran uraian yang termuat dalam hasil analisis data penelitian melalui angket, 
wawancara dan observasi maka kesimpulan dari penelitian sebagai berikut

Berdasarkan Hasil Penelitian ini dapat disimpulkan bahwa pengaruh sosial media facebook terhadap perilaku pelajar yang ada di Desa Pasiang tidak berpengaruh. Berdasarkan hasil Teknik analisis deskriptif dan analisis infrensial pada sosial media facebook terhadap perilaku pelajar menunjukkan bahwa tidak ada perbedaan yang signifikan antara pengaruh sosial media facebook terhadap perilaku pelajar atau dengan kata lain bahwa media sosial facebook tidak berpengaruh terhadap perilaku pelajar. Hal tersebut dapat dibuktikan dengan nilai t hitung $(1,112)<\mathrm{t}$ tabel $(1,677)$, maka dapat di dikatakan bahwa sosial media facebook tidak berpengaruh terhadap perilaku pelajar.

Jadi, dengan demikian hipotesis yang menyatakan "pengaruh sosial media facebook terhadap perilaku pelajar di Desa Pasiang", dapat dikatakan tidak teruji dan tidak dapat diterima.

Berdasarkan hasil penelitian sebagaimana telah dikemukakkan di atas, maka perlu diberikan beberapa saran, antara lain:

1. Kepada remaja hendaknya dapat meluangkan waktunya lebih banyak lagi secara langsung atau tatap muka dengan lingkungan sosialnya.

2. Dan juga hendaknya menambah kegiatan atau aktifitasnya dengan cenderung melepaskan diri dengan hal-hal yang membuatnya melakukan penyimpangan terutama di sosial media.

\section{DAFTAR PUSTAKA}

Ega Dewa Putra. (2014). Menguak Jejaringan Sosial. Tengerang:

Hanafi, Muhammad. (2016). Pengaruh Menggunakan Media Sosial Facebook Terhadap Motifasi Belajar Mahasiswa”. Skripsi Jurusan Ilmu Komunikasi Fakultas Ilmu Sosial Dan Politik Universitas Riau.

Nasrullah, Rulli. (2015). Media Sosial: Prespektif Komunikasi, Budaya Dan Sosioteknologi. Jakarta: Simbiosa Rekatama Media.

Prisgunanto Ilham. (2015). Pengaruh Sosial Media Terhadap Tingkat Kepercayaan Bergaul Siswa. Skripsi Jakarta Selatan: Sekolah Tinggi Ilmu KepolisianPerguruan Tinggi Ilmu Kepolisian.

Syaeba, M. (2019). ETIKA KOMUNIKASI MEDIA SOSIAL FACEBOOK (STUDI EKSPLORASI TERHADAP TINDAKAN BULLYING BAGI MAHASISWA FAKULTAS ILMU SOSIAL DAN ILMU PEMERINTAHAN UNIVERSITAS AL ASYARIAH MANDAR). MITZAL (Demokrasi, Komunikasi dan Budaya): Jurnal Ilmu Pemerintahan dan Ilmu Komunikasi, 1(1).
Sondoklangi, Fransina. (2016). Upaya Guru Ppkn Dalam Mengembangkan Kecerdasan Moral Peserta Didik Di Smp Negeri 3 Mamasa Kabupaten Mamasa. Polewali: Universitas Al Asyariah Mandar.

Sugiono. (2017). Metode penelitian kuantitatif, kualitatif, dan $R \& D$. Bandung: Alfabeta.

Yusuf, Doni Pranata. (2017). Pengaruh Media Sosial Facebook Terhadap Pola Komunikasi Interpersonal Di SDN IV Sudirman Makassar.Departemen Ilmu Komunikasi Fakultas Ilmu Sosial Dan Ilmu Politik Universitas Hasanuddin Makassar. 